\title{
Disciplinární odpovědnost osob ve služebním poměru
}

\section{Disciplinary Responsibility of Persons in Service Relationship}

\author{
Ivo Keisler ${ }^{*}$
}

\begin{abstract}
Abstrakt

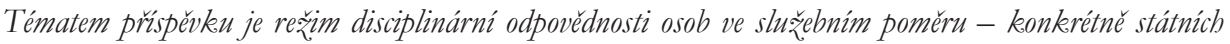
zamèstnancui, prǒslušniku bezpečnostnich sborü a vojáku z povoláni. Autor se nejprve zabývá vybranými otázkami pozitivněprávni úpravy disciplinárni odpovédnosti osob ve služebnim pomèru obsaženév vákonu c. 234/2014 Sb., o státni službě, ve znèni pozdèjš̀ch prèdpisü, zákonu č. 361/2003 Sb., o služebním pomèru prìslušnikì bezpečnostnich sborì, ve znèni pozdèjsǐch prèdpisì, a zákonu č. 221/ 1991 Sb., o vojácich z povolání, ve znèni pozdèjš̀ch prèdpisù. Dále se autor zamýšli nad možností racionální harmonizace obsabu uvedených predpisu stran disciplinárni odpovédnosti a načrtává možná rè̃ení.
\end{abstract}

\section{Klíčová slova}

Slǔ̌ebni pomèr; disciplinárni odpovèdnost; disciplinárni trestání; správni trestání.

\begin{abstract}
The topic of the paper is the disciplinary responsibility of persons in service relationship - namely civil servants, members of security forces and professional soldiers. The author first deals with the selected issues of legislative regulation of disciplinary responsibility of persons in service relationship which is contained in the Act no. 234/2014 Coll., on civil service, as amended, Act no. 361/2003 Coll., on service relationship of members of security forces, as amended, Act no. 221/ 1991 Coll., on professional soldiers, as amended. Further author contemplates the possibility of rational harmonization of the content of those acts regarding disciplinary responsibility and outlines possible solutions.
\end{abstract}

\section{Keywords}

Service Relationship; Disciplinary Responsibility; Disciplinary Punishment; Administrative Punishment.

\section{1 Úvod}

Jak snad není třeba ani podotýkat, počátkem uplynulého roku nabyl účinnosti zákon č. 234/2014 Sb., o státní službě, ve znění pozdějších předpisů (dále jen „zákon o státní službě ${ }^{\prime}$ ), čímž bylo ukončeno dlouholeté čekání na komplexní právní úpravu regulující postavení osob v tzv. civilní větvi státní služby, tedy tzv. státních zaměstnanců. S účinností tohoto předpisu došlo tedy k podstatnému rozhojnění množiny osob působících

\footnotetext{
* Mgr. Ivo Keisler, doktorand, Katedra správní vědy a správního práva, Právnická fakulta Masarykovy univerzity, Brno / Ph.D. student, Department of Administrative Studies and Administrative Law, Faculty of Law, Masaryk University, Brno, Czech Republic / E-mail: ivo.keisler@gmail.com
} 
ve veřejnoprávním služebním poměru, a tedy rovněž osob z činnosti $\mathrm{v}$ rámci tohoto služebního poměru (veřejnoprávně) disciplinárně odpovědných.

Jak plyne z uvedeného, zákon o státní službě není jediným předpisem, z jehož textu vyplývají normy upravující režim služebního poměru fyzických osob vưči státu, stejně jako státní zaměstnanci v režimu tohoto zákona nejsou jedinými osobami ve služebním poměru, které zná český právní řád. Mimo tuto nově kodifikovanou skupinu působí ve služebním poměru, navíc kontinuálně po značně delší časové období, př́íslušníci bezpečnostních sborů v režimu zákona č. 361/2003 Sb., o služebním poměru příslušníků bezpečnostních sborů, ve znění pozdějších předpisů (dále jen ,zákon o př́slušnících bezpečnostních sborư‘), a dále specifická, nicméně rovněž neopominutelná, množina osob ve služebním poměru coby př́islušníci Armády České republiky - vojáci z povolání ve smyslu zákona č. 221/1999 Sb., o vojácích z povolání, ve znění pozdějších předpisů (dále jen ,zákon o vojácích z povolání‘). ${ }^{1}$

Cílem tohoto příspěvku (s možná až přiliš neurčitě formulovaným názvem) je přehledně na jednom místě předestřít základní aspekty pozitivněprávní úpravy disciplinární odpovědnosti $\mathrm{v}$ případě všech tří jmenovaných skupin osob ve služebním poměru, přičemž mimo samotné analýzy textu relevantních právních předpisů je jeho obsahem rovněž vzájemné srovnání pojetí disciplinární odpovědnosti v jednotlivých případech a krátká úvaha nad možnostmi jejich sjednocení, resp. vyšší mírou harmonizace.

\section{Obecně k disciplinární odpovědnosti}

Nelze se zpravidla probírat textem pozitivního práva bez pochopení teoretických pilírư na nichž je tento založen. Disciplinární odpovědnost lze definovat coby odpovědnost vztahující se na porušování vnitroorganizačních vztahů, která nabývá právní formy, jde-li o organizační vztahy upravené právem, ${ }^{2}$ resp. odpovědnost za jednání (nebo opomenutî) narušující disciplínu, tj. kázeň nebo pořádek uvnitř nějakého společenského organismu anebo společenské instituce. ${ }^{3}$ Uvedená definice užívá rovněž pojmu „disciplína“, jenž představuje jednak „podř̌zeni se jednotlivce urǔitému pořádku“, a jednak „stanovený rád činností néjakého organizovanébo celku, pravidla, podle nichž, tento celek funguje a za jejich ž porušení

1 Armáda České republiky sice je veřejným sborem, obdobně jako např. Policie České republiky nebo Hasičský záchranný sbor České republiky, není však na rozdíl od těchto a dalších veřejných sborů, na jejichž příslušníky dopadá zákon o př́slušnících bezpečnostních sborů, navenek vykonavatelem veřejné správy (srov. HENDRYCH, Dušan. In: HENDRYCH, Dušan a kol. Správní právo. Obecná cást. Praha: C. H. Beck, 2012, s. 122), a celkově si její specifická úloha a postavení vyžádaly zvláštní právní úpravu.

2 Srov. PRŮCHA, Petr. Správníprávo. Obecná část. Brno: Doplněk, 2012, s. 410.

3 SLÁDEČEK, Vladimír. Obecné správníprávo. Praha: ASPI, a. s., 2005, s. 170. Srov. HÁCHA, Emil. In: HÁCHA, Emil, HAVELKA, Jiří, HOBZA, Antonín, HOETZEL, Jiří, WEYR, František a kol. Slovník verejného práva československébo $(A-C H)$. Brno: Polygrafia - Rudolf M. Rohrer, 1929, s. 389. 
Lze ulo:̌it sankci. ${ }^{4}$ Existence disciplinární odpovědnosti je pak výrazem potřeby zajistit dodržování předepsaných pravidel v relativně ucelených a stabilizovaných organizačních soustavách, ${ }^{5}$ přičemž disciplinárního deliktu se může dopustit toliko osoba, která má určitý (právnî) vztah k dané organizační soustavě. ${ }^{6}$

Výše obecně definovaná disciplinární odpovědnost není jen konkrétním druhem správněprávní odpovědnosti, nýbrž jedná se o druh odpovědnosti prostupující naprýíc právními odvětvími ${ }^{7} \mathrm{~s}$ ohledem na charakter vztahu, jímž je disciplinárně odpovědná osoba $\mathrm{k}$ př́slušnému společenskému organismu či organizační struktuře vázána, a tím titulu, z jakého tato entita vůči disciplinárně odpovědné osobě vykonává disciplinární pravomoc. ${ }^{8}$ Hovoř́me-li konkrétně o disciplinární odpovědnosti správněprávní, jedná se o odpovědnost osoby, která je ve zvláštních právních vztazích $\mathrm{k}$ určité instituci, se zvláštními právy a povinnostmi vyplývajícími právě z toho služebního, zaměstnaneckého, resp. členského vztahu, prričemž se může jednat o stát (úřednický aparát státu, ozbrojené síly, policie apod.), profesní komory nebo jiné instituce (veřejné vysoké školy, instituce, $\mathrm{v}$ nichž se vykonává trest odnětí svobody apod.).

S ohledem na instituci, $\mathrm{k}$ níž jsou služebním poměrem vázány osoby spadající do režimu trojice výše uvedených zákonů (tím je stát, resp. jeho př́slušná organizační složka), titul, jímž je tento poměr založen (tím je rozhodnutí, tedy vrchnostenský individuální právní akt), a charakter tohoto poměru, je vzhledem $\mathrm{k}$ výše uvedenému nepochybné, že se v př́padě disciplinární odpovědnosti osob ve služebním poměru fungujících v režimu zmíněné trojice zákonů jedná o disciplinární odpovědnost veřejnoprávní (správněprávnî). ${ }^{10,11}$

4 STAŠA, Josef. In: MATES, Pavel a kol. Základy sprámího práva trestního. Praha: C. H. Beck, 2002, s. 79. Srov. HÁCHA, Emil. In: HÁCHA, Emil, HAVELKA, Jiř́, HOBZA, Antonín, HOETZEL, Jiří, WEYR, František a kol. Slovník verégného práva československého $(A-C H)$. Brno: Polygrafia - Rudolf M. Rohrer, 1929, s. 389.

5 PRŮCHA, Petr. Spráuní právo. Obecná cást. Brno: Doplněk, 2012, s. 410.

6 Srov. SLÁDEČEK, Vladimír. Obecné sprámí právo. Praha: ASPI, a. s., 2005, s. 170.

7 PRŮCHA, Petr. Spráuní právo. Obecná část. Brno: Doplněk, 2012, s. 410.

8 V praxi zdaleka není výjimkou vyvozování disciplinární odpovědnosti vyplývající z poměrů soukromoprávního charakteru.

9 Srov. PRÁŠKOVÁ, Helena. In: HENDRYCH, Dušan a kol. Správní právo. Obecná část. Praha: C. H. Beck, 2012, s. 455.

10 Srov. také PRÁŠKOVÁ, Helena. Základy odpovédnosti za správní delikty. Praha: C. H. Beck, 2013, s. 149.

11 Nalézt lze také názor, že charakter odpovědnosti lze interpretovat ze skutečnosti, že o disciplinárním provinění je rozhodováno formou vrchnostenského individuálního správního aktu (VAVERA, František, HULINSKÝ, Petr, MLSNA, Petr, MATES, Pavel, CHRÁSTKOVÁ, Kristina, DOLEŽÍLEK, Jiří, ŠKODA, Jindřich. Zákon o státni služběs spoznámkami. Plzeň: Aleš Čeněk, 2015, s. 149), resp. ze skutečnosti, že rozhodování o disciplinárním deliktu (a trestu za něj) je svěřeno do pravomoci právního orgánu (KOPECKÝ, Martin, PICHRT, Jan. In: PICHRT, Jan a kol. Zákon o stáni služ̨̧é. Komentár. Praha: Wolters Kluwer, a. s., 2015, s. 258). 
Tento závěr vyplývá rovněž z ustálené judikatury Nejvyššího správního soudu, který jednak v rozsudku ze dne 30. 10. 2003, č. j. 6 As 29/2003-97, publ. pod č. 415/2004 Sb. NSS, nesporně dovodil, že služební poměr (v dané věci služební poměr př́islušníka Policie České republiky) je vztahem veřejnoprávním, ${ }^{12}$ a dále z jeho rozhodovací praxe vyplývá, že veřejnoprávnímu charakteru se těší rovněž disciplinární odpovědnost osob ve služebním poměru, viz např. rozsudek ze dne 29. 2. 2012, č. j. 4 Ads 103/2011-149.13 Ve stejném duchu se pak nese rovněž judikatura zvláštního senátu zřízeného podle zákona č. 131/2002 Sb., o rozhodování některých kompetenčních sporů, ve znění pozdějších předpisů, např. jeho usnesení ze dne 17. 8. 2005, č. j. Konf 76/2004-12.

Tuto teoretickou část je nutno zakončit krátkou terminologickou úvahou. Zákon o státnî službě $\mathrm{v}$ př́padě odpovědnosti za porušení vnitroorganizačních vztahů hovoří o odpovědnosti „kárné“; zákon o př́slušnících bezpečnostních sborů a zákon o vojácích z povolání pak v těchto př́padech užívají pojmu odpovědnost „kázeňská““. Oba tyto pojmy jsou v praxi synonymem k pojmu „disciplinární odpovědnost“, přičemž jsem toho názoru, že roztříštěnost terminologie, pro disciplinární trestání typická, byt' je jevem bezesporu nežádoucím, ${ }^{14}$ nečiní v praktické aplikaci disciplinární odpovědnosti vážnější potíže. Výše citovaná i jiná odborná literatura však obecně užívá pouze pojmu „disciplinárni“ , 15 pročež jsem se rozhodl pro účely svého př́íspěvku nehovořit o odpovědnosti kárné, nýbrž disciplinární, kterýžto pojem považuji za doktrinálně vhodnější. ${ }^{16}$ Obdobná situace nastává v případě označení disciplinárního deliktu, který zákon o státnî službě označuje coby „provinění“, zatímco zákony o příslušnících bezpečnostních sborů a o vojácích z povolání coby „přestupek“. Rovněž zde jsem se rozhodl pro účely tohoto př́spěvku užívat doktrinálně nejvhodnější pojem „delikt“.

\section{Disciplinárně odpovědná osoba ve služebním poměru}

Příspěvek pojednává o disciplinární odpovědnosti množiny fyzických osob, pro něž používá zkratku „osoba ve služebním poměru“, čímž obecně myslí osoby, jejichž služební poměr je regulován zákony o státní službě, o příslušnících bezpečnostních sborů a o vo-

12 Konkrétně Nejvyšší správní soud uvedl, že „... věci vyplývajici ze služebního pomèru prǐslušníkũ Policie České republiky upravenébo víše cit. zákonem nejsou věcmi pracovnimi, ani je nelze pro jejich povahu považovat za věci soukromoprávni. Služebni pomèr byl charakterizován jako institut verejného práva, byl považován za právni pomèr státně zamèstnanecký. Dîvody byly spatrovány v tom, že vaniká mocenským aktem služebníbo funkcionáre a po celou dobu svébo prüběbu se výrazně odlišuje od poméru pracouního, keterý je naopak typickým pomèrem soukromoprávním, jehož úăastnici maji rovné postaveni. To se projevuje v právni úpravě služebni káznè, možnosti ukládat kázeñské odměny a tresty, omezené možnosti propouštèní, úpravè slư̌ebního volna, nárocích na dovolenou, zvláštními nároky pri skončeni služebního poméru a také zulástnimi ustanoveními o ř́zeni prè služebnimi funkecionárí. "

$13 \mathrm{~V}$ dané věci šlo o disciplinární odpovědnost příslušníka Hasičského sboru České republiky.

14 Svědčícím o poměrně neracionálním postupu zákonodárce.

15 Alespoň veškerá, na kterou jsem doposud narazil.

16 Vyjma zákonem stanovených názvů orgánů, které disciplinární pravomoc vykonávají. 
jácích z povolání. Byt' se v minulosti objevovaly úvahy o faktickém dělení disciplinární odpovědnosti zaměstnanců civilní větve veřejné správy a disciplinární odpovědnosti členů bezpečnostních sborů, z hlediska teoretického se jedná o jeden a týž druh odpovědnosti. ${ }^{17}$ Považuji za vhodné krátce se zaměřit na přesné vymezení konkrétních osob, které pod tento režim fakticky spadají.

Zákon o státní službě v \6 definuje státního zaměstnance, tedy osobu, na níž dopadá jeho osobní působnost, coby , fyzickou osobu, která byla prĭjata do služebního pomèru a zarazena na služebni misto nebo jmenována na služebni misto predstavenébo k. výkonu některé z činností uvedených v $\int 5$ ", která zároveň nespadá do taxativního negativního výčtu obsaženého $\mathrm{v} \int 2$ daného předpisu. Př́islušníkem bezpečnostního sboru ve smyslu zákona o př́íslušnících bezpečnostních sborů je fyzická osoba vykonávající službu v některém z taxativně uvedených bezpečnostních sborů. ${ }^{18,19}$ Co se ve smyslu tohoto zákona rozumí výkonem služby, pak blíže předestírá jeho $\int 1$ odst. $4 .^{20}$ Nejjednodušší definici obsahuje zákon o vojácích z povolání, který vojáka z povolání definuje coby „občana, který vojenskou činnou službu vykonává jako svoje zaměstnáni“; ‘21 samotná definice „,výkonu služby“ je obsažena v \24 odst. 1 zákona o vojácích z povolání. ${ }^{22}$

Nikoliv všechny osoby spadající do výše definovaných množin jsou ve skutečnosti rovněž disciplinárně odpovědné. Zákon o státní službě explicitně stanoví, že za disciplinární delikt neodpovídá náměstek ministra vnitra pro státní službu. ${ }^{23}$ Toto vynětí z disciplinární odpovědnosti sice neznamená, že by náměstek ministra vnitra pro státní službu nebyl povinen dodržovat služební kázeň, resp. nebyl odpovědný za její porušení, jelikož zákon o státní službě v $\int 60$ odst. 3 coby jeden z důvodů pro jeho odvolání24 ze služeb-

17 POŠVÁŘ́, Jaroslav. Disciplinární delikty. Verejná správa. 1937, roč. 7, č. 3, s. 12. Srov. KOPECKÝ, Martin, PICHRT, Jan. In: PICHRT, Jan a kol. Zákon o stáni sluø̌bě. Komentár. Praha: Wolters Kluwer, a. s., 2015, s. 258.

$18 \int 1$ odst. 1 zákona o př́íslušnících bezpečnostních sborů.

19 Těmi jsou Policie České republiky, Hasičský záchranný sbor České republiky, Celní správa České republiky, Vězeňská služba České republiky, Generální inspekce bezpečnostních sborů, Bezpečnostní informační služba a Úřad pro zahraniční styky a informace.

20 Podle něj se výkonem služby rozumí ,a) úkony a činnosti realizujici oprávnèni a povinnosti stanovené právními predpisy upravijicimi puisobnost bezpečnostnich sbori, b) soustred'ování, vyhodnocování a evidováni informaci a údaju

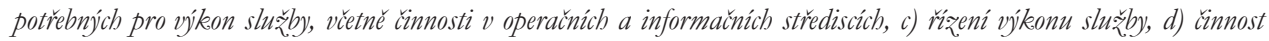

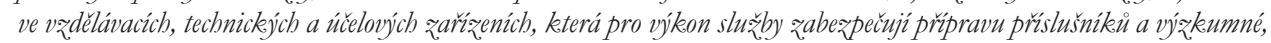
technické a dalši podminky, a to v rozsahu stanoveném reditelem bezpečnostního sboru, a e) plnèni úkolu Bezpečnostni informačni služby a Úradu pro zabranični styky a informace (dále jen „zpravodajská služba"). "

21 \ 2 odst. 1 zákona o vojácích z povolání.

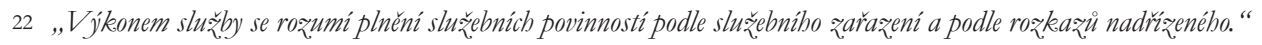

$23 \int 88$ odst. 2 zákona o státní službě.

24 Eventuálně pro odvolání personálního ředitele sekce pro státní službu, pokud vykonává pravomoci náměstka pro státní službu z důvodu, že služební místo náměstka pro státní službu není obsazeno. 
ního místa uvádí rovněž porušení služební kázně zvlášt' závažným způsobem, ${ }^{25}$ nejedná se však v takovém případě o disciplinární trestání v pravém slova smyslu, ale o specifický typ odpovědnosti. ${ }^{26}$

\section{Služební kázeň a disciplinární delikt}

Jak plyne z již uvedeného, (veřejnoprávnî) disciplinární odpovědnost osoby ve služebním poměru se odvijí od dodržení či nedodržení právem stanovených pravidel vnitroorganizačních vztahů, tedy zachování vnitřní kázně či pořádku, resp. nesplnění služební povinnosti. ${ }^{27}$ Bez dalšího jsou tyto pojmy značně neurčité a je proto velmi vhodné jejich obsah v př́slušných právních předpisech formálně vymezit.

S pojmem kázeň či služební kázeň operují všechny tři relevantní zákony, přičemž každý z nich si jeho rozsah pro své účely definuje vlastním způsobem. Zákon o státní službě stanoví, že služební kázní se rozumí „rádné plnèní povinností státního zamèstnance vyplývajicich mu z.právnich predpisu, které se vatabuji ke službě v jím vykonávaném oboru služby, ze služebnich predpisu a zpř́kazư. " 28 Obdobnou definici služební kázně nalezneme rovněž v zákoně o př́slušnících bezpečnostních sborů, pro jehož účely služební kázeň spočívá $v$ „nestranném, rádném a svědomitém plnèni sluřebnich povinnosti prǐslušnika, kterép pro nĕj vyplývaji z právních predpisü, služebnich predpisu a rozkazui. "29

Na rozdíl od dvou uvedených předpisů zákon o vojácích z povolání sice rovněž hovoří o služební kázni, neobsahuje však vlastní definici tohoto pojmu. ${ }^{30}$ Tento na první pohled nedostatek se dá nicméně poměrně jednoznačně řešit výkladem ustanovení upravujícím skutkovou podstatu disciplinárního deliktu, ${ }^{31}$ eventuálně analogie s definicemi obsaženými ve zbylých uvedených předpisech. Kázní ve smyslu zákona o vojácích z povolání je tedy nutno rozumět řádné a svědomité plnění povinností vojáka, které pro něj vyplývají z právních předpisů nebo vojenských řádů, předpisů a rozkazů.

Na služební kázeň, jíž jsou osoby ve služebním poměru povinny dodržovat, úzce navazuje rovněž skutková podstata disciplinárního deliktu, přičemž na rozdíl od ostatních pododvětví správního trestání či trestání soudního, v př́padě trestání disciplinárního již tradičně existuje pouze jedna skutková podstata, formulovaná navíc relativně vágně. ${ }^{32}$ Zákon

\footnotetext{
25 Po boku dopuštění se zaviněného jednání, jímž je narušena důstojnost jeho funkce nebo ohrožena důvěra v jeho nestranné, odborné a spravedlivé rozhodování.

26 Obdobně jako v prrípadě odnětí hodnosti vojáku z povolání (viz níže).

27 POŠVÁŘn, Jaroslav. Disciplinární delikty. Verénná správa. 1937, roč. 7, č. 3, s. 12.

$28 \int 87$ zákona o státní službě.

$29 \int 46$ odst. 1 zákona o příslušnících bezpečnostních sborů.

30 Odpovídající „nápovědu“ neobsahuje ani důvodová zpráva k původnímu návrhu zákona.

31 \51 odst. 1 zákona o vojácích z povolání.

32 Srov. POŠVÁŘ, Jaroslav. Disciplinární delikty. Veréjná správa. 1937, roč. 7, č. 3, s. 12.
} 
o státní službě volí velice úspornou cestu, když konstatuje, že naplnění skutkové podstaty disciplinárního deliktu nastává $\mathrm{v}$ případě zaviněného porušení služební kázně. ${ }^{33}$ Stejného konceptu se drží rovněž zákon o príslušnících bezpečnostních sborů, přestože namísto použití již definovaného pojmu „služební kázeň“ je v jeho př́padě zvolen přístup explicitnější. Disciplinárním deliktem je podle něj „zavinèné jednáni, které porušuje služebni povinnost, ale nejde o trestný čin nebo o jednáni, keteré má znaky prestupku nebo jinébo správníbo deliketu. "34 Dále pak výslovně uvádí, že za disciplinární delikt ,se považuje $i$ dosahováni neuspokojiuých výsledkì ve výkonu služby uvedené v závéru služebního hodnoceni" "35 ke kterémužto závěru lze rovněž dospět ze samotné definice služební kázně, jež vyžaduje, aby plnění povinností př́slušníka bezpečnostního sboru bylo řádné a svědomité. Zásadně odlišný koncept neprrináší ani zákon o vojácích z povolání, který stanoví, že „kázeňským přestupkem se rozumí zaviněné jednání, které je v rozporu s právními předpisy nebo vojenskými řády, předpisy a rozkazy, nejde-li o jiný správní delikt nebo není-li trestné podle trestního zákona. 'B6

Mimo výše citované pozitivněprávní požadavky nelze opomenout, že pro spáchání disciplinárního deliktu je dále, stejně jako v př́padě jiných správních deliktů, s ohledem na ustálenou judikaturu Nejvyššího správního soudu, ${ }^{37}$ nutné, aby byla naplněna rovněž materiální stránku tohoto deliktu, tedy aby vykazoval určitou míru společenské nebezpečnosti.

Nad rámec nedodržení služební kázně dopadá zákon o vojácích z povolání rovněž na situace, kdy se osoba ve služebním poměru vojáka z povolání dopustí jednání naplňující skutkovou podstatu přestupku podle speciálního zákona, ${ }^{38}$ když tento stanoví, že takové jednání vojáka se vyřídí jako disciplinární delikt. ${ }^{39}$ Obdobné pravidlo, byt’ ne tak výslovně formulované, je obsaženo rovněž v zákoně o př́íslušnících bezpečnostních sborů, dle nějž lze vést disciplinární řízení a udělit disciplinární sankce rovněž v př́padě jednání, které má znaky přestupku podle speciálního právního předpisu. ${ }^{40,41}$ Vojáci z povolání

$33 \int 88$ odst. 1 zákona o státní službě.

$34 \int 50$ odst. 1 věta první zákona o př́slušnících bezpečnostních sborů.

$35 \int 50$ odst. 1 věta druhá ibid.

36 \51 odst. 1 zákona o vojácích z povolání.

37 Např. rozsudek ze dne 31. 5. 2007, č. j. 8 Afs 17/2007-135, publ. pod č. 1338/2007 Sb. NSS.

38 Tedy at’ už podle zákona č. 200/1990 Sb., o přestupcích, ve znění pozdějších předpisů, nebo kterýkoliv jiný z nepřeberného množství předpisů správního práva obsahujících vlastní skutkové podstaty přestupků.

$39 \int 51$ odst. 2 zákona o vojácích z povolání.

40 \ 186 odst. 2 a 51 odst. 2 zákona o př́slušnících bezpečnostních sborů.

41 Srov. také rozsudek Nejvyššího správního soudu ze dne 19. 5. 2010, č. j. 1 As 36/2010-44, v němž bylo konstatováno, že pokud jednání, které má znaky přestupku, jehož se dopustil př́íslušník bezpečnostních sborů, projedná jako přestupek místně prríslušný obecní úřad namísto toho, aby je projednal př́slušný služební funkcionář v rrízení podle zákona o příslušnících bezpečnostních sborů, je výsledné rozhodnutí obecního úřadu nicotné, protože jej vydal absolutně věcně nepříslušný správní orgán. 
a př́slušníci bezpečnostních sborů jsou tak, na rozdíl od státních zaměstnanců, fakticky vyňati z pravomoci správních orgánů běžně vedoucích přestupkové řízení, ${ }^{42}$ a rovněž v těchto situací je př́islušné předpisy svěřují do pravomoci orgánů vykonávajících nad mini pravomoc disciplinární, a to bez ohledu na skutečnost, zda se tohoto jednání měla př́slušná osoba ve služebním poměru dopustit při samotném výkonu služby nebo mimo něj. ${ }^{43} \mathrm{~V}$ př́padě vojáků z povolání je řízení o jednání se znaky přestupku převážně vedeno a sankce (eventuálně ochranná opatřenî) za něj nadále ukládány zcela v režimu konkrétních zvláštních předpisů, ${ }^{44}$ zatímco zákon o př́islušnících bezpečnostních sborů obsahuje vlastní výčet sankcí, a jak v otázce jejich ukládání, tak stran procesních pravidel na zvláštní právní předpisy odkazuje jen ve vybraných př́padech. ${ }^{45} \mathrm{~S}$ ohledem na skutečnost, že se v př́padě vynětí uvedených osob ve služebním poměru z působnosti obecných orgánů činných v rrízení o přestupcích a svěření této pravomoci orgánům v daných př́padech vykonávajících disciplinární pravomoc nejedná o otázku disciplinární odpovědnosti ve výše uvedeném slova smyslu, nebudu se tímto tématem podrobně zabývat.

Jak zákon o prríslušnících bezpečnostních sborů, tak zákon o vojácích z povolání přímo v ustanovení obsahujícím skutkovou podstatu disciplinárního deliktu explicitně negativně vymezují jeho rozsah tak, že v něm vyjímají skutky naplňující zároveň některou ze skutkových podstat trestný činů, jiných správních deliktů a $\mathrm{v}$ př́padě př́islušníků bezpečnostních sborů také přestupků. Zákon o státní službě obdobně explicitní negativní vymezení neobsahuje. Z S 96 ods.t 4 písm. g) zákona o státní službě sice vyplývá, že má-li předmětné jednání znaky přestupku, jiného správního deliktu či trestného činu, je orgán vykonávající disciplinární pravomoc povinen postoupit věc orgánu, který má pravomoc o tomto jednání podle zvláštních předpisů vést rúzení, ${ }^{46,47}$ tedy jinému správnímu orgánu nebo orgánu činnému v trestním řízení, přičemž pokud byl tímto orgánem státní zaměstnanec za daný skutek pravomocně potrestán, nelze jej již projednat $\mathrm{v}$ disciplinárním řízení. ${ }^{48} \mathrm{~V}$ praxi tedy nebude docházet k zásadním obtížím, stran určení, které jednání má být ve výsledku projednáno v disciplinárním řízení a které již nikoliv.

42 Nikoliv však již řízení o jiném správním deliktu a s ohledem na čl. 40 odst. 1 Listiny základních práv a svobod už vůbec ne řízení trestní.

43 Velmi zajímavé srovnání s touto koncepcí poskytuje \ 17 odst. 1 zákona č. 45/2016 Sb., o službě vojáků v záloze, který nabude účinnosti k 1. 7. 2016 (viz \50 tohoto zákona) a který rovněž zřizuje výluku z působnosti orgánů obecně vedoucích řízení o přestupcích, nicméně pouze pro případy, v nichž se voják v záloze jednání majícího znaky přestupku dopustí při výkonu služby nebo v př́mé souvislosti s jejím výkonem.

44 \51 odst. 2 zákona o vojácích z povolání.

45 Např. \ 51 odst. 3 či \ 189 zákona o příslušnících bezpečnostních sborů.

46 Rízení o přestupku jiném správním deliktu nebo trestního řízení.

47 Srov. KOPECKÝ, Martin, PICHRT, Jan. In: PICHRT, Jan a kol. Zákon o stáni službě. Komentár. Praha: Wolters Kluwer, a. s., 2015, s. 274.

$48 \mathrm{~V}$ opačném př́padě by se jednalo o porušení zásady ne bis in idem (srov. rozsudek velkého senátu Evropského soudu pro lidská práva ve věci Zolotukhin proti Rusku ze dne 10. 2. 2009, stížnost č. 14939/03). 
Bez ohledu na to je však disciplinárním deliktem státního zaměstnance veškeré zaviněné jednání porušující služební kázeň, i když dosahuje zároveň společenské nebezpečnosti např. trestného činu. ${ }^{49}$

Společným jmenovatelem pro všechny tři předpisy je požadavek, aby porušení služební kázně bylo zaviněné, ${ }^{50}$ nicméně pouze zákon o př́slušnících bezpečnostních sborů upravuje vlastní definici zavinění. Konkrétně v \50 odst. 2 a 3 tento zákon stanoví, že nedbalostní zavinění je u disciplinárního deliktu dáno, jestliže př́slušník „a) věděl, že svým

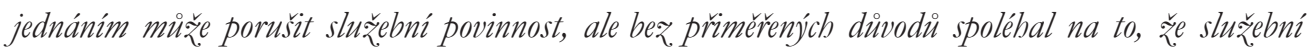
povinnost neporuši, nebo b) nevédèl, že svým jednáním mǐže porušit služebni povinnost, ač to vžbledem k okolnostem vědèt mél a mohl. "; úmyslnou formu zavinění je pak nutno hledat v případech, kdy př́slušník „a) chtěl svým jednáním porušit služebni povinnost, nebo b) vědèl, že svým jednáním

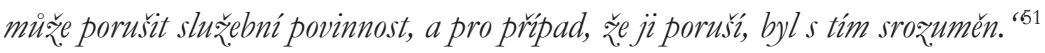

Jak ve vztahu k zákonu o státní službě konstatují např. Kopecký a Pichrt, v takovém př́padě je nutno vyložit daný pojem způsobem, jak ho zná právní teorie a jak z něj vycházejí jiné zákony, které jednotlivé druhy zavinění vymezují, ${ }^{52}$ tedy a simili jak zákon č. 200/1990 Sb., o přestupcích, ve znění pozdějších předpisů, tak především zákon o př́slušnících bezpečnostních sborů. Stejně lze tento závěr použít v případě zákona o vojácích z povolání.

Skutková podstata disciplinárního deliktu je tedy naplněna ve chvíli, kdy př́slušná osoba ve služebním poměru zaviněně koná či nekoná v rozporu s povinností dodržovat služební kázeň a své povinnosti (a to jak úmyslně, tak nedbalostně). Nikoliv však každé jednání, které je formálně v rozporu s požadavky na dodržování služební kázně, je nutno považovat za disciplinární delikt. Ve všech třech výše předestřených př́padech je stanovena povinnost řídit se nejen obecně závaznými či vnitřními předpisy, ale rovněž povinnost jednat podle př́kazů či rozkazư ${ }^{53}$ udělených př́slušnou nadřízenou osobou. Tato povinnost však není bezmezná, ba naopak ve všech třech pro tento prríspěvek relevantních př́padech je stanoven explicitní zákaz vykonat prŕkaz či rozkaz, jímž by došlo

49 Viz \ 12 odst. 2 zákona č. 40/2009 Sb., trestního zákoníku, ve znění pozdějších předpisů.

50 Čímž je učiněno za dost teoretickoprávním předpokladům (BOHADLO, David, POTĚŠIL, Lukáš, POTMĚŠIL, Jan. Správni trestáni z hlediska praxe a judikatury. Praha: C. H. Beck, 2013, s. 5).

51 Nelze odhlédnout od podobnosti této definice (či skupiny definic) s textem $\int 4$ odst. 1 a 2 zákona č. 200/1990 Sb., o přestupcích, ve znění pozdějších předpisů.

52 KOPECKÝ, Martin, PICHRT, Jan. In: PICHRT, Jan a kol. Zákon o stání sluð̌bě. Komentár. Praha: Wolters Kluwer, a. s., 2015, s. 259.

53 Tyto pojmy lze považovat za synonyma (TOMEK, Petr. Zákon o služebnim pomèru př̌slušnikủ bezpečnostních sbori s komentárem k 1. 7. 2012. Olomouc: Anag, spol. s r. o., 2012, s. 180), přičemž snad s ohledem na skutečnost, že oproti civilní větvi státní služby se v př́padě bezpečnostních sborů ve smyslu zákona o př́slušnících bezpečnostních sborů a Armády České republiky jedná o sbory „,vojensky organizované“ (srov. rozsudek Nejvyššího správního soudu ze dne 4. 11. 2004, č. j. 3 Ans 2/2004-60), zvolil zákonodárce této skutečnosti bližší výraz „rozkaz“, ačkoliv tím obdobně jako výše založil právně jazykovou nekonzistentnost. 
ke spáchání trestného činu (v případě státních zaměstnanců rovněž správního deliktu), ${ }^{54}$ resp. povinnost odeprrít v daném případě jeho splnění. ${ }^{55}$ Odepření poslušnosti vůči nadřízené osobě spočívající v nesplnění příkazu či rozkazu pak logicky nemůže být ani disciplinárním deliktem. ${ }^{56}$

\section{Sankce a jejich ukládání}

Zásadní otázkou spojenou s disciplinární odpovědností je určení sankcí, které je možné v rámci její realizace ukládat. Každý z trojice předpisů obsahuje vlastní taxativní výčet sankcí, hierarchicky odstupňovaných podle intenzity, s níž zasahují do osobní sféry disciplinárně trestané osoby. ${ }^{57,58}$

Zákon o státní službě (nebyla-li situace vyřešena pouze písemnou výtkou ${ }^{59,60}$ ) umožňuje, je-li rozhodnuto o vině státního zaměstnance, uložit disciplinární sankci v podobě ,a) pisemné dưtky, b) sniženi platu až o $15 \%$ na dobu až 3 kalendárnich měsicui, c) odvoláni ze služebního mista predstaveného, nebo d) propuštèní ze služebního pomèru. "61

Zákon o př́slušnících bezpečnostních sborů obsahuje hned sedm typů sankcí, nicméně tento počet není výsledkem snahy zákonodárce o poskytnutí nadstandardního manévrovacího prostoru př́íslušným orgánům při snaze vybrat nejpřiléhavější trest pro deliktní jednání, ale je dán skutečností, že (jak bylo výše uvedeno) tento zákon obsahuje rovněž

$54 \int 85$ odst. 3 zákona o státní službě a $\int 46$ odst. 3 zákona o příslušnících bezpečnostních sborů.

$55 \int 48$ odst. 2 zákona o vojácích z povolání.

56 Zajímavou skutečností je, že v návaznosti na tento zákaz ani jeden z relevantní trojice relevantních předpisů nezakládá výluku z protiprávnosti v případě, že konkrétní protiprávní jednání či opomenutí je činěno na základě př́kazu či rozkazu vedoucímu ke spáchání trestného činu, či v případě státních zaměstnanců rovněž správního deliktu.

57 Srov. TOMEK, Petr. Zákon o služebnim poméru prǔslušníkủ bezpečnostních sboru s komentárem k. 1. 7. 2012. Olomouc: Anag, spol. s r. o., 2012, s. 189. Srov. TOMEK, Petr, DLUHOŠ, Jiří, HEMZA, Stanislav. Služební pomér vojákư zpovolání. Olomouc: Anag, spol. s r. o., 2003, s. 124. Srov. KOPECKÝ, Martin, PICHRT, Jan. In: PICHRT, Jan a kol. Zákon o stáni službě. Komentár. Praha: Wolters Kluwer, a. s., 2015, s. 264.

58 Zpravidla při rozhodování odrážející závažnost jednání, jímž byla naplněna skutková podstata disciplinárního deliktu.

59 Tímto způsobem je podle \88 odst. 3 zákona o státní službě možno řešit „drobné nedostatky ve službě“.

60 Za zamyšlení stojí otázka charakteru této výtky, tedy zda již tato samotná formální výtka představuje disciplinární sankci. S ohledem na skutečnost, že právní úpravu v zákoně o státní službě lze stále označit za čerstvou, minimálně co do možnosti vzniku adekvátní judikatury, jež by tuto otázku vyřešila. $\mathrm{Na}$ druhou stranu komentářová literatura obdobě jako v př́padě výtky dle \88a zákona č. 6/2002 Sb., o soudech a soudcích, ve znění pozdějších předpisů, či dle $\int 30$ odst. 3 zákona č. 283/1993 Sb., o státním zastupitelství, ve znění pozdějších předpisů, považuje předmětnou formální výtku nikoliv za sankci, ale toliko za prostředek plnění řídících funkcí a kontrolních pravomocí vưči podřízeným svěřený představenému nebo služebnímu orgánu; při jehož využívání je však nutno respektovat základní zásady činnosti správních orgánu, včetně zásady legitimního očekávání (Srov. VAVERA, František, HULINSKÝ, Petr, MLSNA, Petr., MATES, Pavel, CHRÁSTKOVÁ, Kristina, DOLEŽÍLEK, Jiří, ŠKODA, Jindřich. Zákon o státni službě s poznámkami. Plzeň: Aleš Čeněk, 2015, s. 149.).

61 \ 89 odst. 2 zákona o státní službě. 
skupinu sankcí ukládaných v případě, že je v disciplinárním řízení projednáván skutek mající znaky prestupku. Mimo tyto sankce je za disciplinární delikty v pravém slova smyslu možno uložit sankci v podobě „a) pisemnébo napomenutí, b) snížení základního tarifu

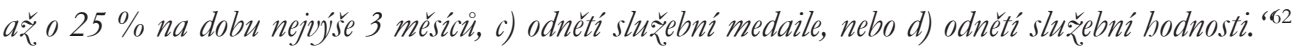
Na první pohled se může zdát, že na rozdíl od zákona o státní službě zákon o př́slušnících bezpečnostních sborů neobsahuje žádnou sankci vedoucí k ukončení služebního poměru disciplinárně trestaného příslušníka bezpečnostního sboru. Ve skutečnosti tomu tak není, jelikož podle \42 odst. 1 písm. e) zákona o prríslušnících bezpečnostních sborů coby jednu situaci vedoucí k povinnému propuštění ze služebního poměru stanoví rovněž uložení disciplinární sankce odnětí služební hodnosti podle $\int 51$ odst. 1 písm. d) daného předpisu. Není však možno opomenout, že k ukončení služebního poměru dochází nikoliv z titulu samotného rozhodnutí, jímž je uložena sankce, ale zvláštního rozhodnutí, které na něj navazuje, což s sebou nese další důsledky. ${ }^{63}$

Přestože rovněž zákon o vojácích z povolání rovněž umožňuje projednat v disciplinárním řízení jednání mající znaky přestupku, v rámci palety disciplinárních sankcí obsahuje pouze ty, které jsou ukládány za disciplinární delikt, a to konkrétně ,a) napomenutí, b) písemnou dritku, c) výstrahu pro neodpovédný výkon služby, nebo d) snižžni služebníbo platu až o $15 \%$ až na dobu 6 mésicư. " ${ }^{64}$ Jestli bylo výše uvedeno, že i přes absenci explicitní sankce může být $\mathrm{v}$ důsledku disciplinární odpovědnosti ukončen služební poměr př́slušníka bezpečnostního sboru, v prrípadě vojáků z povolání tato možnost skutečně dána není. Mimo ukončení služebního poměru propuštěním na základě některého z důvodů taxativně jmenovaných v \19 odst. 1 zákona o vojácích z povolání, mezi nimiž se však žádná reakce na výsledek disciplinárního rrízení (konkrétně v něm udělenou sankci) nenachází, nicméně ten podle $\int 21$ odst. 3 tohoto zaniká rovněž odnětím hodnosti, které je však vydáváno ve zvláštním řízení odlišném od disciplinárního. ${ }^{65,66} \mathrm{Na}$ rozdíl od dvou výše uvedených skupin osob ve služebním poměru tak disciplinární odpovědnost vojáků z povolání má spíše varovný dopad, a tedy plní především preventivně-výchovnou funkci. ${ }^{67}$

$\mathrm{S}$ ohledem na skutečnost, že $\mathrm{v}$ prípadě všech tři skupin osob ve služebním poměru existuje pouze jedna skutková podstata, nejsou výše citované sankce přiřazeny ke konkrétním jednáním, jimiž je tato skutková podstata naplněna. Výjimku z tohoto tvrzení do jisté míry v případě zákonů o služebním poměru a příslušnících bezpečnostních sborů představuje uložení sankce nejtvrdší, resp. sankce, která má za následek ukončení

$62 \int 51$ odst. 1 písm. a) až d) ibid.

63 Mezi nimi např. nutnost vést další řízení.

$64 \int 53$ odst. 2 zákona o vojácích z povolání.

65 \145 odst. 1 písm. e) a \147 a násl. zákona o vojácích z povolání.

66 Vzájemný vztah těchto dvou rrízení je pritom zdrojem mírných nejasností (viz TOMEK, Petr, DLUHOŠ, Jiří, HEMZA, Stanislav. Služebni pomèr vojáki z povolání. Olomouc: Anag, spol. s r. o., 2003, s. 83.).

67 Viz např. PRŮCHA, Petr. Správní právo. Obecná cást... s. 391. 
služebního poměru, ${ }^{68}$ jež je v případě těchto zákonů vázáno na splnění zvláštních podmínek v těchto předpisech obecně vymezených. ${ }^{69}$ Ve zbytku je volba konkrétní sankce ponechána na úvaze konkrétního orgánu vykonávajícího disciplinární pravomoc, který však nemůže ignorovat konkrétní okolnosti projednávaného př́padu, a to v zákonem stanoveném rozsahu. ${ }^{70,71}$

Všechny tři shora uvedené předpisy umožňují od uložení disciplinární sankce rovněž upustit, uzná-li př́slušný orgán, že k nápravě osoby ve služebním poměru postačí „pouhé“ projednání věci v rámci disciplinárního řízení. ${ }^{72}$

\section{Orgány vykonávající disciplinární pravomoc}

Bavíme-li se o základních aspektech právní úpravy disciplinární odpovědnosti, nelze opomenout určení orgánů, které vykonávají nad disciplinárně odpovědnými osobami disciplinární pravomoc. Bylo-li možno spatřovat ve výše uvedeném textu mezi pojetím $\mathrm{v}$ případech tří relevantních skupin osob ve služebním poměru nuance, zde je již možno hovořit o značných rozdílech. Ty vyplývají pochopitelně ze skutečnosti, že každá z uvedených skupin, ba dokonce jednotlivé podskupiny v jejich rámci ${ }^{73}$ podléhají speciální právní úpravě, která často s ohledem na objektivní okolnosti stanovuje zvláštní organizační strukturu instituce, k níž jsou konkrétní osoby služebním poměrem vázány.

Disciplinární ř́zení podle zákona o státní službě v první instanci vede tř́íčlenná kárná komise prvního stupně zřizovaná v rámci každého služebního úřadu, ${ }^{74}$ má-li tento služební úřad alespoň 25 státních zaměstnanců, eventuálně kárná komise prvního stupně zřízená u nadř́izeného služebního úřadu, ${ }^{75}$ není-li předešlá podmínka splněna, popř́ípadě kárná

$68 \mathrm{~V}$ př́padě vojáků z povolání nalezneme podobnou limitaci v př́padě rozhodnutí o odnětí hodnosti (viz \ 21 odst. 1 zákona o vojácích z povolánî).

$69 \mathrm{~V} \int 89$ odst. 3 větě druhé zákona o státní službě demonstrativně; v \186 odst. 7 zákona o příslušnících bezpečnostních sborů taxativně.

70 Ten je v příslušných ustanoveních (〔 89 odst. 3 věta první zákona o státní službě. \186 odst. 5 zákona o prríslušnících bezpečnostních sborů, $\int 54$ odst. 3 zákona o vojácích z povolání) vymezen sice na první pohled odlišným způsobem, ve skrze se však od sebe jednotlivá pojetí neliší.

71 Rezignovat nelze ani na základní principy výkonu veřejné správy (ukázkově zásadu legitimního očekávání obsaženou v \ 2 odst. 4 zákona č. 500/2004 Sb., správního řádu, ve znění pozdějších předpisů), správního řízení a trestního práva (viz rozsudek Nejvyššího správního soudu ze dne 31. 5. 2007, č. j. 8 As 29/2007-121, publ. pod č. 1338/2007 Sb. NSS).

72 \ 89 odst. 6 zákona o státní službě, \ 186 odst. 8 zákona o příslušnících bezpečnostních sborů a \54 odst. 1 zákona o vojácích z povolání.

73 Např. jednotlivé, speciálními předpisy zrrízené, bezpečnostní sbory.

74 Tedy dle $\int 4$ odst. 1 ve spojení s $\int 3$ zákona o státní službě v rámci ministerstva vnitra a jiného správního úradu, jestliže je zřízen zákonem a je zákonem výslovně označen jako správní úřad nebo orgán státnî správy.

75 Tím je služební úřad, který je podle jiného zákona nadřízeným správním úřadem ( 4 odst. 4 zákona o státní službě). 
komise prvního stupně zř́zená v Ministerstvu vnitra, nemá-li služební úřad nadřízený úrad..$^{76}$ Zvláštnímu režimu se podle $\int 92$ odst. 2 zákona o státní službě těší vedoucí služebního úřadu, $v$ jehož př́padě vykonává disciplinární pravomoc kárná komise prvního stupně zř́zená u nadřízeného služebního úřadu, není-li ho, kárná komise prvního stupně zrrízená v Ministerstvu vnitra. ${ }^{77}$ Jelikož je disciplinární řízení podle zákona o státní službě dvojinstanční, nelze nezmínit orgán rozhodující ve druhém stupni, jímž je, bez ohledu na organizační strukturu příslušného odvětví státní správy, (opět tříčlenná) kárná komise druhého stupně zřízená v rámci Ministerstva vnitra. ${ }^{78,79} \mathrm{~V}$ případě státních zaměstnanců je tedy rozhodování o jejich disciplinární odpovědnosti svěřeno orgánům kolektivním, a tedy orgánům, které se na konečném rozhodnutí usnášejí hlasováním. ${ }^{80}$

Orgán vedoucí disciplinární řízení a udělující disciplinární sankce podle zákona o příslušnících bezpečnostních sborů označuje tento předpis coby služebního funkcionáře. ${ }^{81}$ Obecně se jedná o ředitele bezpečnostního sboru či v jím stanoveném rozsahu vedoucího organizační části bezpečnostního sboru. ${ }^{82}$ Konkrétní určení služebního funkcionáře v celé řadě speciálních př́padů je pak obsaženo v \2 odst. 1 až 5 zákona o př́íslušnících bezpečnostních sborů.

Také disciplinární řízení podle zákona o př́slušnících bezpečnostních sborů je dvojinstanční, přičemž orgánem rozhodujícím ve druhém stupni je služební funkcionář nadřízený služebnímu funkcionáři, který vydal prvoinstanční rozhodnutí, ${ }^{83}$ jehož určení podléhá obsahu zvláštního předpisu, jenž upravuje organizační strukturu konkrétního bezpečnostního sboru. Výjimku z toho konstatování představuje rozhodnutí ředitele školy nebo školského zařízení, které není organizační částí bezpečnostního sboru, ${ }^{84}$ v jehož př́padě je odvolacím orgánem Ministerstvo vnitra, a dále jde-li o rozhodnutí vedoucího organizační části ministerstva nebo rektora policejní akademie, jež v odvo-

76 『92 odst. 1 zákon o státní službě.

77 Důvodem této odlišnosti je logicky skutečnost, že v souladu s $\int 10$ odst. 1 zákona o státní službě je vedoucí služebního úřadu služebním orgánem, tedy orgánem, jenž jmenuje a odvolává členy kárné komise podle $\int 91$ odst. 2 tohoto zákona.

78 \ 91 odst. 1 , \ 93 a \ 168 odst. 1 zákona o státní službě.

79 Tato kárná komise samožrejmě není totožná s kárnou komisí prvního stupně zřízenou u Ministerstva vnitra.

80 『 91 odst. 5 zákona o státní službě.

$81 \int 2$ odst. 6 zákona o prŕslušnících bezpečnostních sborů.

$82 \int 2$ odst. 1 ibid.

$83 \int 190$ odst. 6 věta první zákona o příslušnících bezpečnostních sborů.

$84 \mathrm{~V}$ praxi se jedná v podstatě pouze o rozhodnutí týkající se příslušníků Policie České republiky služebně zařazených na středních a vyšších odborných školách Ministerstva vnitra (TOMEK, Petr. Zákon o služebnim pomèru prǐslušnikè bezpečnostních sboru s komentárem k 1. 7. 2012. Olomouc: Anag, spol. s r. o., 2012, s. 31). 
lacím řízení přezkoumává ministr vnitra. ${ }^{85} \mathrm{Na}$ rozdíl od zákona o státní službě zde není dán jediný orgán rozhodující o všech podaných odvoláních bez ohledu na to, kterým orgánem byla vydána jimi napadená rozhodnutí, což se odráží rovněž na určení orgánu rozhodujícího o řádném opravném prostředku podaném proti rozhodnutí orgánu, jenž sám stojí na vrcholu organizační soustavy. ${ }^{86}$ Tím je podle \} 1 9 1 \text { služební funkcionář, } který napadené rozhodnutí vydal, a to v rámci řízení o rozkladu.

$\mathrm{Na}$ rozdíl od zákona o státní službě, který razí cestu orgánů kolektivních, svěřuje tedy zákon o př́slušnících bezpečnostních sborů výkon disciplinární pravomoci ve všech stupních naopak do rukou konkrétně určeného jednotlivce. Jedinou výjimkou představuje ojedinělá rozhodovací pravomoc Ministerstva vnitra v odvolacím řízení a do jisté míry taky skutečnost, že $\mathrm{v}$ rámci řízení o rozkladu činí služební funkcionář rozhodnutî na základě návrhu poradní komise. ${ }^{87}$

Velmi svébytná je pak struktura orgánů podle zákona o vojácích z povolání, dle nějž disciplinární rrízení vede a disciplinární sankce ukládá tzv. orgán s kázeňskou pravomocí, jímž se v souladu s \50 odst. 2 zákona o vojácích z povolání rozumí v celém rozsahu prezident a ministr obrany, v rozsahu stanoveném ve vojenských řádech pak služební orgány a nadřízení. Určení konkrétního orgánu je ponecháno na zvláštní právní úpravě, přičemž reflektuje organizační strukturu touto právní úpravou stanovenou. ${ }^{88}$ Rovněž disciplinární řízení podle zákona o vojácích z povolání je dvojinstanční, a je tedy potřeba zmínit také orgán oprávněný rozhodovat ve druhém stupni. Tím je orgán s kázeňskou pravomocí, který je nadřízen tomu, jenž o uložení kázeňského trestu rozhodl, ${ }^{89}$ určený opět s ohledem na organizační strukturu vyplývající ze zvláštních předpisů. Výjimku ze zmíněné dvojinstančnosti řízení představují případy, v nichž v první instanci rozhoduje prezident, proti jehož rozhodnutí není možno podat odvolání. ${ }^{90,91}$

Stejně jako v případě př́slušníků bezpečnostních sborů, rovněž o disciplinární odpovědnosti vojáků z povolání rozhoduje jednotlivec. Tomu nicméně zákon o př́slušnících bez-

85 \ 190 odst. 6 věta druhá zákona o příslušnících bezpečnostních sborů.

86 Tedy ministra vnitra nebo vládou určeného člena vlády (『 191 odst. 1 zákona o př́islušnících bezpečnostních sborů).

$87 \int 194$ zákona o př́slušnících bezpečnostních sborů.

88 Viz \ 13 zákona č. 219/1999 Sb., o ozbrojených silách České republiky, ve znění pozdějších předpisů.

$89 \int 57$ odst. 1 věta třetí zákona o vojácích z povolání.

$90 \int 57$ odst. 1 věta čtvrtá zákona o vojácích z povolání.

91 Byt' zde zákon o vojácích z povolání hovoří (nepřesně) pouze o odvolání, je nutno rozumět tímto nemožnost podání jakéhokoliv řádného opravného prostředku, s ohledem rovněž na skutečnost, že $\mathrm{v}$ úvahu nepřipadá ani podání rozkladu podle \ 152 zákona č. 500/2004 Sb., správního řádu, ve znění pozdějších předpisů (srov. např. POTĚŠIL, Lukáš. In POTĚŠIL, Lukáš, HEJČ, David, RIGEL, Filip, MAREK, David. Spránní rád. Komentár. Praha: C. H. Beck, 2015, s. 680 a násl. Srov. JEMELKA, Luboš, PONDĚLÍČKOVÁ, Klára, BOHADLO, David. Spránni rád. Praha: C. H. Beck, 2008, s. 479). Jedinou možností jak zvrátit výsledek takového prvoinstančního rozhodnutí je tedy podání žaloby podle $\int 65$ a násl. zákona č. 150/2002 Sb., soudního řádu správního, ve znění pozdějších předpisů. 
pečnostních sborů umožňuje pro účely rozhodování o udělování disciplinárních sankcí zrrídit poradní orgán (poradní komisi), ve kterých jsou zejména zástupci hodnostního sboru. Do určení rozsahu, v němž je prríslušný orgán oprávněn tento výkon provádět, významně vstupuje skutečnost pro dvě výše uvedené skupiny osob ve služebním poměru netypická, a sice tvorba vnitřních předpisů. Ustanovení \50 odst. 3 zákona o vojácích z povolání zakládá právo prezidenta, coby z titulu čl. 63 odst. 1 písm. c) ústavního zákona č. 1/1993 Sb., Ústavy České republiky, ve znění pozdějších předpisů, vrchního velitele ozbrojených, sil prijimout podrobnou úpravu vojenského disciplinárního práva v rámci vojenského řádu. ${ }^{92}$

\section{Minimální nástin disciplinárního rrízení}

Detailní rozbor procesní stránky disciplinárních řízení vedených s osobami ve služebním poměru by vydal na více, než samostatný př́spěvek, není tedy v možnostech tohoto textu předmětnou otázku detailně předestř́t.

$\mathrm{V}$ případě všech tří skupin osob ve služebním poměru se pro disciplinární řízení použije zákon č. 500/2004 Sb., správní řád, ve znění pozdějších předpisů (dále jen „správní řád“), ${ }^{93}$ přičemž s jistou mírou nadsázky lze hlavní rozdíly mezi jednotlivými procesními úpravami měřit podle toho, do jaké míry jeho plnou aplikaci dané předpisy neumožňují, at' už z titulu výslovného vyloučení, či existence speciální úpravy.

Zákon o státní službě a zákon o vojácích z povolání jsou stran vlastní zvláštní úpravy poměrně střídmé - omezují se skutečně jen na kvantitativně malé, byt' kvalitativně ne zrovna nevýznamné, oblasti. Zákon o vojácích z povolání výslovně vylučuje aplikaci konkrétních ustanovení správního rádu, ${ }^{94}$ nicméně nad rámec této výluky obsahuje skutečně jen poměrně malé množství zvláštních ustanovení týkajících se především otázky procesních lhůt a otázky přezkumu rozhodnutí v řízeních podle tohoto zákona vedených. ${ }^{95}$ Zákon o státní službě, jak bylo uvedeno, nezakládá žádnou výslovnou výluku z aplikace správního řádu. Co do zvláštních ustanovení, těch je v př́padě tohoto předpisu užíváno především pro otázku zahájení řízení a jeho zastavení, ${ }^{96}$ dále pak pro řízení o odvolání. ${ }^{97}$ Zcela opačný přístup zákonodárce zvolil v případě zákona o př́slušnících bezpečnostních sborů, jenž sice použití správního řádu rovněž nevylučuje, ale na mnoha místech

92 Tím je v praxi Základní rád ozbrojených sil České republiky (Zákl-1) z roku 2001.

93 Zákon o státní službě jeho použití deklaruje výslovně v \160, u zákona o vojácích z povolání tato skutečnost vyplývá a contrario z $\int 144$ a v případě disciplinárního řízení vedeného s příslušníky bezpečnostních sborů se pak použije subsidiárně na základě \ 1 odst. 2 zákona č. 500/2004 Sb., správního řádu, ve znění pozdějších předpisů (jelikož jeho použití text prŕíslušného předpisu nevylučuje).

$94 \int 144$ zákona o vojácích z povolání.

95 Včetně speciální 60 denní lhůty pro podání správní žaloby v \151 zákona o vojácích z povolání.

96 \94 a násl. zákona o státní službě.

97 \168 zákona o státní službě. 
obsahuje vlastní speciální úpravu mající pochopitelně aplikační přednost. Toto tvrzení neplatí pouze pro otázky disciplinárního řízení, ale o správních řízeních v režimu tohoto zákona vůbec. V ustanoveních části dvanácté zákona o př́islušnících bezpečnostních sborů jsou uvedena zvláštní pravidla otázky zahájení řízení a určení, kdo je jeho účastníkem, přes zastoupení či náležitosti vydaného rozhodnutí, až po zcela zvláštní pravidla uplatněná pouze v ř́zení disciplinárním. ${ }^{98,99}$

Je-li v této části v podstatě pouze hovořeno o subsidiární aplikaci správního řádu a jejím rozsahu v konkrétních prrípadech, hodí se poznamenat, že existují rovněž úvahy nad tím, zda je vůbec subsidiární aplikace tohoto předpisu pro účely disciplinárního řízení vhodná. Z poslední doby lze jmenovat např. Bražinu, podle nějž by bylo, především s ohledem na skutečnost, že správní řád není předpisem primárně určeným k projednávání správních deliktů, ${ }^{100}$ shodnější mimo tohoto předpisu pro účely disciplinárního řízeni subsidiárně aplikovat ustanovení zákona č. 141/1961 Sb., trestního řádu ve znění pozdějších předpisů. ${ }^{101}$ Tato koncepce není v oblasti disciplinárního trestání úplně nová - využívá se např. v disciplinární odpovědnosti vykonávané Českou advokátní komorou. ${ }^{102}$ Osobně jsem co do vhodnosti aplikace právě tohoto předpisu střiženého na míru soudnímu řízení skeptický, a klonil bych se spíše k úvahám vhodnosti založení aplikovatelnosti právní úpravy obsažené v zákoně č. 200/1990 Sb., o přestupcích, ve znění pozdějších předpisů (či od 1. 7. 2017 zákona č. 250/2016 Sb., o odpovědnosti za přestupky a řízení o nich ${ }^{103}$ ), coby předpisu vytvářeného pro potřeby správního trestání a jeho eventuálních specifik ve spojení se správním řádem; ${ }^{104}$ nicméně toto téma by rovněž vydalo na samostatný článek. At’ tak či onak, většina ostatních předpisů upravujících postup v disciplinárních řízeních, pokud užití jiných právních předpisů přímo nevylučují, ${ }^{105} \mathrm{v}$ současné době připouští106 či přímo zakládá použití správního řádu.

98 \186 a násl. zákona o příslušnících bezpečnostních sborů.

99 Již z této skutečnosti vyplývá, že rozdílů mezi konkrétními procesními rámci disciplinárního řízení vedeného v režimu relevantní trojice zákonů, je více než dostatek.

100 A jak bylo již výše uvedeno, při jejich projednání se s ohledem na judikaturu Nejvyššího správního soudu užije principů trestního práva.

101 BRAŽINA, Radislav. Zahájení kárného řízení ve věcech kárného provinění státních zaměstnanců. In: KYSELOVSKÁ, Tereza, KADLUBIEC, Vojtěch, PROVAZNÍK, Jan, SRINGINSFELDOVÁ, Nelly, VIRDZEKOVÁ, Alica. COFOL A 2015: the Conference Proceedings. Brno: Masarykova univerzita, 2015, s. 506-514.

102 S 35e zákona č. 85/1996 Sb., o advokacii, ve znění pozdějších předpisů.

$103 \int 114$ zákona o odpovědnosti za přestupky a řízení o nich.

104 Nebot’ jak zákon č. 200/1990 Sb., o přestupcích, ve znění pozdějších předpisů, tak zákon č. 250/2016 Sb., o odpovědnosti za prestupky a řízení o nich, neobsahují, s ohledem na subsidiární působnost správního řádu, zcela komplexní procesní úpravu.

105 Např. \ 68 odst. 1 zákona č. 111/1998 Sb., o vysokých školách, ve znění pozdějších předpisů.

106 Ve smyslu $\int 1$ odst. 2 a jiných relevantních ustanovení správního řádu. 
Ve zbytku, s ohledem na rozsah př́spěvku, ponechávám procesní úpravu prozatím stranou, s příslibem, že se $\mathrm{k}$ ní ve své budoucí tvorbě určitě navrátím.

\section{Možnosti harmonizace}

Výše byly ve vzájemném srovnání představeny základy jednotlivých pojetí disciplinární odpovědnosti osob ve služebním poměru. Nyní je čas na zamyšlení nad jejich možnou vzájemnou harmonizací.

Otázka proveditelnosti přijetí jedné komplexní právní úpravy (jednotného kodexu) regulující právní postavení všech zaměstnanců veřejné správy, resp. všech osob ve služebním poměru, které jsou v současné době rozděleny do skupin podléhajícím režimu speciálních předpisů, ${ }^{107}$ se $\mathrm{v}$ minulosti stala opakovaně předmětem úvah jak mezi odbornou veřejností, tak na úrovni vlády, ${ }^{108}$ přičemž vždy byla konstatována př́lišná komplikovanost jednotného řešení, což je patrno i na současném stavu pozitivního práva. ${ }^{109}$ Účelem tohoto příspěvku není načrtnout podobu jednotné právní úpravy regulace právního postavení osob ve služebním poměru jako takové, ba dokonce ani jednotné právní úpravy jejich disciplinární odpovědnosti. Níže uvedené řádky obsahují zamyšlení nad možnostmi (částečné) harmonizace právní úpravy disciplinární odpovědnosti osob ve služebním poměru za respektování objektivně odůvodněných odlišností jednotlivých z výše popsaných pojetí.

Z výše uvedeného textu poměrně jasně vyplývá, že byt' právní rámce disciplinární odpovědnosti jednotlivých skupin osob ve služebním poměru vznikaly v různých obdobích a jejich text byl vytvářen $\mathrm{v}$ gesci různých vládních rezortů, nejen základy, ale často také jejich konkrétní rozvedení jsou v řadě př́padů velmi podobné. $\mathrm{Na}$ druhou stranu uvedené okolnosti jejich vzniku vedou ke skutečnosti, že v právní úpravě narážíme na řadu nuancí, které nesplňují podmínku objektivní potřeby. Na jednu stranu se nabízí úvaha, proč by vlastně tyto odlišnosti nemohly existovat, když se zde bavíme o zvláštní právní úpravě dopadající na poměrně ucelené skupiny osob. Není však možno opomenout, že tyto osoby spojuje minimálně skutečnost, že všechny z nich jsou ve služebním poměru vůči státu, přičemž osobně nevidím důvod, proč by se naopak neodůvodněné rozdíly

107 A to včetně úředníků územních samosprávných celků fungujících v režimu zákona č. 312/2002 Sb., ve znění pozdějších předpisů, které ani nelze považovat za osoby ve služebním poměru v pravém slova smyslu.

$108 \mathrm{Viz}$ např. Analýza možnosti jediné komplexni úpravy právního postavení zamèstnancủ ve verejné správě [Online]. Dostupné z http://www.vlada.cz/assets/urad-vlady/statni-sluzba/aktualni-informace/anal_za.pdf [cit. 14. 3. 2016].

109 Navíc s ohledem na objektivní (legitimnî) rozdíly mezi obsahem služebního poměru uvedených osob ve služebním poměru lze předpokládat, že eventuální jednotný kodex by byl vnitřně strukturován do samostatných částí, v nichž by byla obsažena značná část speciální úpravy pro každou z nich, a je tedy otázkou, do jaké míry by bylo takové řešení účelné. 
v jejich právním postavení měly vyskytovat; ${ }^{110}$ jakkoliv by se nabízela protiteze založená na závěru, že zásadní aplikační potíže řečené rozdíly (naštěstî) nepřinášejí.

\subsection{Harmonizace terminologie}

První z otázek není prakticky nijak zásadní, nicméně teoreticky se jedná skutečně o negativní skutečnost. Je jí již výše jednou rozebraná otázka terminologie užívané v oblasti disciplinární odpovědnosti. Pokud by snad někdy mělo skutečně být uvažováno o jisté harmonizaci některých otázek disciplinární odpovědnosti osob ve služebním poměru, považoval bych za vhodné sjednotit rovněž terminologii jednotlivými předpisy užívanou, a to nikoliv $\mathrm{v}$ duchu některého $\mathrm{z}$ pojmů uvedených ve třech pro tento příspěvek relevantních zákonech, ale užitím jednotného, z hlediska teorie práva nejpřesnějšího, pojmu disciplinární“

Po zamyšlení volá rovněž otázka označení, jehož př́islušné předpisy užívají pro samotné protiprávní jednání - disciplinární delikt. Zatímco zákon o státní službě hovoří o „provinění“, zbylé dva předpisy používají dokonce pojmu „přestupek“ (byt' ne bez přívlastku), poměrně zavádějícím s ohledem na jeho obecný zákonem stanovený význam. ${ }^{111} \mathrm{Z}$ tohoto důvodu a důvodů uvedených o odstavec výše jsem toho názoru, že by bylo vhodnější ustálit terminologii na pojmu „disciplinární delikt“.

\subsection{Harmonizace skutkové podstaty}

Již výše bylo konstatováno, že formulace skutkové podstaty disciplinárního deliktu se ve všech třech uvedených případech, byt' formálně odlišně pojatá, v podstatě neliší. Jedinou výjimku z tohoto konstatování představuje otázka jejîho negativního vymezení, která jednotně rešena není. V režimu zákonů o příslušnících bezpečnostních sborů a o vojácích z povolání je disciplinárním deliktem jednání porušující služební kázeň, „nejde-li o jiný správni deliket nebo neni-li trestné podle trestního zákona“, resp. pokud „nejde o trestný čin nebo o jednáni, které má znaky prestupku nebo jinébo správního deliktu "Fakticky tento stav panuje rovněž $\mathrm{v}$ př́padě disciplinárního deliktu státního zaměstnance, nicméně zákon o státní službě formální úpravu negativního vymezení neobsahuje.

Nejsem si vědom toho, že by za řečeným stavem stál výslovný úmysl zákonodárce, stejně jako důvodu, který by mohl k dané odlišnosti v pojetí objektivně vést. Nevidím tedy ani rozumný důvod, proč by měla být skutková podstata disciplinárního deliktu v případě státních zaměstnanců formálně upravena takto odlišně od zbylých dvou skupin osob ve služebním poměru, a to nikoliv pouze $z$ estetických pohnutek (ve snaze unifikovat text daných předpisů za každou cenu). Definice disciplinárního deliktu obsahující nejen

\footnotetext{
110 Přece jen se nejedná o stejnou situaci jako např. u jednotek zájmové samosprávy (především samosprávných komor s povinným členstvím), kde vysokou míru rozmanitosti často odůvodňuje aktivní využití zákonem garantované autonomie.

111 Viz \2 odst. 1 zákona č. 200/1990 Sb., o přestupcích, ve znění pozdějších předpisů.
} 
vymezení pozitivní, ale rovněž vymezení negativní je navíc konkrétnější a přesnější než pouhé konstatování, že se jedná o zaviněné porušení služební kázně. Obsažení negativního vymezení disciplinárního deliktu také v zákonu o státní službě by proto bylo vhodnější rovněž s ohledem na teoretickoprávní, dlouholetou judikaturou potvrzený, požadavek na dostatečně konkrétní formulaci skutkové podstaty veřejnoprávního deliktu. ${ }^{112}$

\subsection{Harmonizace sankcí}

Celkem vděčným tématem stran teoretických úvah je vždy otázka stanovení sankcí. Jak jsem uvedl již dříve $v$ jiném textu príspěvku, ${ }^{113}$ jednou z potíží současné úpravy disciplinární odpovědnosti státních zaměstnanců je místy nedostatečná rozmanitost palety sankcí s ohledem na rozmanitost jednání, které mohou naplnit skutkovou podstatu disciplinárního deliktu a jejich intenzity; ${ }^{114}$ ve vzájemném srovnání všech tř́ skupin osob ve služebném poměru se tento problém rovněž objevuje, není však jediným.

Předně je nutno uvést, že by bylo vhodné zamyslet se nad možností zavedení (po vzoru zákona o státní službě) formálního postupu pro řešení drobných nedostatků ve výkonu služby, jenž by v daných situacích poskytl flexibilní možnost účinného upozornění na konkrétní nedostatek, ${ }^{115}$ bez nutnosti vést samotné disciplinární řízení.

Palety sankcí ve všech třech případech začínají od nejmírnějších, jimiž jsou sankce „napomínacího" charakteru, přičemž zákony o státní službě a o př́ílušnících bezpečnostních sborů upravují jednu, zákon o vojácích z povolání hned trri. První potíž v této oblasti je druhu terminologického, jelikož zákon o státní službě hovoří o „písemné důtce“, zákon o příslušnících bezpečnostních sborů ve stejném významu o „písemném napomenutí “ a zákon o vojácích z povolání v rozdílném významu používá pojmy oba. ${ }^{116}$ Podstatnější je však poněkud paradoxně úvaha, zda je skutečně nutné užívat hned trojice různých, intenzitou se od sebe přiliš zásadně nelišících „napomínacích“ sankcí. Jsem toho názoru, že jisté odstupňování v této oblasti, ukázkově ve formě písemného napomenutí a nad ním stojící (intenzivnějšî) písemné důtky, vhodné je, nicméně existenci sankce třetí, navíc nemající o moc rozdílnější dopad do osobní sféry osoby obviněné

112 Srov. např. nález Ústavního soudu ze dne 12. 4. 1994, sp. zn. Pl. ÚS 43/93, nebo rozsudek Evropského soudu pro lidská práva ve věci Kokkinakis proti Recku ze dne 25. 5. 1993, stížnost č. 14307/88 (aplikovatelné s ohledem na již výše zmíněný rozsudek Nejvyššího správního soudu ze dne 31. 5. 2007, č. j. 8 As 29/2007-121, publ. pod č. 1338/2007 Sb. NSS).

113 KEISLER, Ivo. Disciplinární odpovědnost státních zaměstnanců. In: SKULOVÁ, Soňa, KLIKOVÁ, Alena, VALDHANS, Jiří. DNY PRÁVA 2015 - DAYS OF LAW 2015. Část IX. - Veréjná služba ve veřejné správě (a to i jako služba verejnosti). Brno: Masarykova univerzita, 2016, s. 179-198.

114 Tato výtka směřuje především k sankci v podobě snížení platu, která by mohla, ve srovnání např. s ekvivalentní právní úpravou účinnou v Polské republice, obsahovat větší rozmezí, at' už co se týče procenta, o nějž lze plat snížit, tak doby, na níž lze toto snížení uložit.

115 Namísto eventuální pouhé neformální domluvy.

116 Přesněji hovoři o napomenutí bez dalšího a o písemné důtce. 
ze spáchání disciplinárního deliktu, již považuji za nadbytečnou. Uvažujeme-li zde tedy o harmonizaci sankcí, jeví se mi jako vhodné ponechání (resp. v př́padě zákona o státní službě a zákona o příslušnících bezpečnostních sborů zavedení) dvojice mírnějších „napomínacích“ sankcí, kteréžto řešení umožňuje jednak volbu odpovídající sankce s ohledem na charakter jednání naplňujícího skutkovou podstatu disciplinárního deliktu, a dále nevytváŕí príliš komplikovanou hierarchii. ${ }^{117}$

Dalším typem sankce, obsaženým ve všech třech výše citovaných sankčních paletách, je sankce v podobě snížení platu na určité omezené období. Jak bylo již výše uvedeno, zákon o státní službě umožňuje snížení platu až o $15 \%$ na dobu až 3 kalendářních měsíců, zákon o př́slušnících bezpečnostních sborů až o $25 \%$ na dobu nejvýše 3 měsíců a zákon o vojácích z povolání o $15 \%$ až na dobu 6 měsíců. ${ }^{118} \mathrm{~V}$ duchu svých již dřive vyjádřených myšlenek musím konstatovat, že sankci limitovanou pouhými 15\% co do snížení platu a jen třemi měsíci, co do maximální doby, na níž lze toto snížení uložit, považuji jednak za v maximální výši nedostatečně intenzivně zasahující do osobní sféry disciplinárně trestaného a s ohledem na nevelké rozpětí zákonných mantinelů hypoteticky nedostačující k uložení sankce přiléhající závažnosti jednání, kterým byla skutková podstata disciplinárního deliktu naplněna. ${ }^{119}$

Další zajímavou skutečností je, že zatímco zákon o státní službě shodně se zákonem o vojácích z povolání hovoří o snížení „platu“, tedy částky sestávající ze všech jeho složek, ${ }^{120}$ zákon o př́slušnících bezpečnostních sborů umožňuje snížit pouze jeho základní tarif, tedy pouze sice nezanedbatelnou, avšak stále jen jeho dílčí část, přičemž zbylé složky může dotyčný příslušník bezpečnostního sboru i po rozhodnutí pobírat v plné výši. ${ }^{121}$ S ohledem na výše opakovanou snahu u navýšení manévrovacího prostoru rozhodujících orgánů, stejně jako na evidentní neopodstatnění této odlišnosti, bych jako ideální řešení viděl zavedení možnosti snížit rovněž v případě příslušníků bezpečnostních sborů plat v celé jeho výši.

Coby ideální kombinaci maximálních limitů bych pak z výše uvedených důvodů spatřoval v možnosti snížit osobě ve služebním poměru coby sankci za disciplinární delikt plat až o $25 \%$ na dobu až 6 měsíců. Ani jeden z uvedených předpisů tuto kombinaci

$117 \mathrm{~V}$ prŕpadě snahy o co největší jednoduchost by bylo možno sjednotit jednotlivá pojetí na pouhém jednom druhu napomínací sankce, nicméně to by šlo proti snaze o poskytnutí dostatečného manévrovacího prostoru v rámci rozhodování $\mathrm{v}$ disciplinárním rrízení.

118 Je vidět, že formulace této sankce jsou ve všech třech př́ípadech podobné, avšak přesto dosti odlišné.

119 Jednoduše mohou nastat situace, $\mathrm{v}$ nichž sankce $\mathrm{v}$ podobě ani ne pětinového snížení platu (dokonce na pouze čtvrt roku) nestačí $\mathrm{k}$ dostatečnému potrestání pachatele disciplinárního deliktu (ve vztahu ke konkrétnímu jednání, kterého se dopustil) a sankce vedoucí ke zrušení jeho služebního poměru by byla neúměrně prísnou.

120 \176 zákona o státní službě a \67 zákona o vojácích z povolání, srov. TOMEK, Petr, DLUHOŠ, Jiř́, HEMZA, Stanislav. Služební pomèr vojákư zpovolání. Olomouc: Anag, spol. s r. o., 2003, s. 124.

$121 \int 113$ zákona o príslušnících bezpečnostních sborů. 
nezná, nicméně v praxi existující př́klad lze nalézt v čl. 114 odst. 1 zákona č. Dz.U. 2008 Nr 227 poz. 1505, o służbie cywilnej, ve znění pozdějších předpisů, tedy Polském zákoně o státní službě.

Poslední v pořadí jsou sankce mající za následek ukončení služebního poměru. Zde je podle mého na místě především úvaha, zda by nebylo vhodné v př́ípadě vojáků z povolání sjednotit řízení o disciplinární odpovědnosti s odpovědností vedoucí $\mathrm{k}$ odnětí hodnosti. Jak vyplývá z popisu jednání, za nějž je možno vojáku z povolání odejmout jeho hodnost, ${ }^{122}$ a tedy v podstatě rozhodnout o zániku jeho služebního poměru, je patrné, že se jedná o jednání spočívající v porušení služební kázně, a jedná se tedy de facto o výkon disciplinární pravomoci, ovšem podléhající zvláštnímu režimu. Možnost v rámci výkonu disciplinární pravomoci uložit sankci mající za následek ukončení služebního poměru s konkrétní osobu je v př́ipadě zbylých dvou skupin osob ve služebním poměru standardní a nespatřuji zvláštního důvodu, proč by tomu mělo být v př́padě vojáků z povolání jinak. Samozřejmě by nebylo nutné přejímat pojetí uplatněné u zbylých dvou skupin osob ve služebním poměru v plném rozsahu - nadále by mohlo např. setrvat zvláštní určení osob, které by tuto sankci v rámci disciplinárního řízení mohly udělit, ${ }^{123}$ např. s tím rozdílem, že $\mathrm{v}$ př́padech, kdy by bylo disciplinární rúzení původně zahájeno u jiného orgánu, by jim byla věc po zjištění „potřebné“ závažnosti deliktního jednání postoupena.

Dále je pak možno uvažovat, zda by nebylo vhodné rovněž v př́padě příslušníků bezpečnostních sborů stanovit, že k pozbytí služebního poměru dochází již samotným rozhodnutím o odnětí služební hodnosti, kteréžto rozhodnutí, jak bylo již uvedeno, pouze zakládá důvod pro popuštění příslušníka z bezpečnostního sboru.

\subsection{Harmonizace orgánů vykonávajících disciplinární pravomoc}

Jak bylo již výše upozorněno, nejvyšší míra rozdílnosti mezi trojicí relevantních předpisů spočívá v určení orgánů, které vykonávají disciplinární pravomoc. S ohledem na to, že tyto orgány kopírují organizační strukturu jednotlivých veřejných sborů či správních úradů, nelze reálně uvažovat o jednoduchém a rychlém kroku vedoucím k jejímu harmonizování (a je otázka, zda by to skutečně bylo účelné). Na druhou stranu je možno uvažovat o konkrétním charakteru těchto orgánů.

O disciplinární odpovědnosti státních zaměstnanců rozhoduje orgán kolektivní, zatímco o disciplinární odpovědnosti zbylých dvou skupin osob ve služebním poměru zpravidla orgán monokratický (vedoucí osoba příslušné organizační složky). I když ani jedno z uvedených pojetí není možno označit za jednoznačně špatné (stejně jako dobré), mám

122 Lze tak učinit v př́padě úmyslného zvlášt’ závažného porušení služebních povinností (\21 odst. 1 zákona o vojácích z povolání).

123 Těmi jsou v př́padě odnětí hodnosti generála prezident, ve zbytku pak ministr obrany ( $\int 21$ odst. 2 zákona o vojácích z povolánî). 
obecně za to, že vhodnějším z nich je svěření rozhodovací pravomoci do rukou kolektivního orgánu, už jen proto, že skýtá větší potenciál stran nezávislosti rozhodování, ${ }^{124}$ stejně jako eliminace hrozby ovlivnění obsahu rozhodnutí v závislosti na konkrétním rozmaru jednotlivce. $\mathrm{V}$ praxi by tato cesta obnášela $\mathrm{v}$ podstatě pouze odnětí pravomoci rozhodovat o disciplinárních otázkách osobě k tomu v současné době oprávněné, ${ }^{125}$ tedy zpravidla vedoucí osobě konkrétní organizační složky, a její předání disciplinární komisi, která bude pro tyto účely ustanovena. Coby vzorová úprava mohou pochopitelně posloužit přiléhavá ustanovení zákona o státní službě, řešící např. otázky ustavení konkrétní komise. Popsaná změna v pojetí by podle mého nepředstavovala zásadní problém ani pro bezpečnostní sbory a ozbrojené síly, které, jak bylo již uvedeno, užívají „,vojenskýc způsob organizace založený především na rozhodování jednotlivce. ${ }^{126}$

\subsection{Otázka odpovědnosti za jednání mající znaky přestupku}

Výše jsem uvedl, že se dále nehodlám podrobně zabývat otázkou řešení přestupků spáchaných př́slušníky bezpečnostních sborů a vojáky z povolání, nicméně nelze si odpustit obecnou úvahu nad nutností existence tohoto speciálního postupu. Osobně nejsem př́znivcem vynětí z pravomoci orgánů s obecnou působností, co se správního trestání týče, resp. k takovému př́istupu nevidím zásadní důvod. Obecně se uvádí, že za vynětím stojí potřeba ochrany nezávislého výkonu činnosti, kterou příslušníci bezpečnostních sborů a vojáci z povolání vykonávají v rámci zajištění bezpečnosti státu a jeho obyvatel. $\mathrm{Na}$ druhou stranu toto zdůvodnění zdaleka nepokrývá veškerá existující jednání mající znaky přestupku. Př́ikladem budiž situace řešená v rozsudku Nejvyššího správního soudu ze dne 14. 4. 2011, č. j. 3 Ads 48/2011-94, v níž se příslušník bezpečnostního sboru bez jakékoliv souvislosti s plněním služebních povinností dopustil jednání naplňujícího skutkovou podstatu přestupku proti bezpečnosti a plynulosti provozu na pozemních komunikacích. ${ }^{127}$ Zmínit lze dále velmi specifické přestupky z oblasti stavebnictví, sociálněprávní ochrany dětí či ochrany životního prostředí, u nichž lze rovněž jen stěží hledat smysl zvláštního režimu pro rozhodování o nich. ${ }^{128}$

124 Přece jen, byt’ by př́ślušná komise (či jinak nazvaný orgán) byla složena z členů konkrétní organizační složky, je $\mathrm{v}$ tomto prípadě dána větší záruka zachování potřebného nadhledu a odstupu od projednávané věci, např. ve chvilích, kdy porušení služební kázně spočivá v nerespektování příkazu vedoucího organizační složky, jenž zároveň vykonává disciplinární pravomoc, a je tady ve věci svým způsobem zainteresován.

125 Samozřejmě spolu s provedením dalších nutných změn, $\mathrm{k}$ tomuto kroku se vážících.

126 Navíc nelze opomenout, že zákon o vojácích z povolání již ustavování komisí, sice pouze coby poradního orgánu, v rámci rozhodování v disciplinárním řízení umožňuje.

127 V rozhodné době upraveného v $\ 22$ odst. 1 písm. f) bod 8 a \ 22 odst. 1 písm. l) zákona č. 200/1990 Sb., o přestupcích, ve znění účinném do 31. 7.2011.

128 Navíc orgány, které se běžně aplikací speciálních předpisů upravujících dané skutkové podstaty nezabývají, a tedy zpravidla s nimi nemají ani potřebné praktické zkušenosti. 
Pokud bych měl souhlasit s opodstatněností vynětí řečených osob ve služebním poměru z pravomoci orgánů obecně rozhodujících v řízení o přestupcích, jednalo by se rozhodně o vynětí limitované, a to pouze na jednání mající znaky přestupku, jehož se daná osoba dopustila při výkonu služby nebo v prrímé souvislosti s jejím výkonem. Ke zvážení však dávám rovněž možnost úplného upuštění od jakéhokoliv vynětí z pravomoci uvedených orgánů a tedy zrušení zvláštního procesního režimu daného příslušníkům bezpečnostních sborů a vojákům z povolání.

\section{Závěr}

Přijetím, resp. účinností zákona o státní službě konečně dosáhla právní úprava postavení osob ve služebním poměru vưči státu takřka komplexního rozsahu, je ovšem roztříštěná do trojice právních předpisů, což má mimo jiné za následek výskyt větších či menších rozdílů v konkrétních pravidlech vztahujících se k jednotlivým skupinám osob ve služebním poměru, jejich disciplinární odpovědnosti nevyjímaje. Jak ukázaly výše se nacházející rádky, základní stavební kameny pojetí disciplinární odpovědnosti v režimu zákonů o státní službě, o prríslušnících bezpečnostních sborů a o vojácích z povolání jsou totožné, nicméně v širším provedení, a to nikoliv jen jeho detailech, lze nalézt řadu dílčích odlišností. Možnost vzájemného srovnání textu hned trojice právních předpisů, navíc ze sféry jak civilní větvě státní správy, tak sféry bezpečnostních sborů, ${ }^{129}$ poskytuje nový pohled na konkrétní pozitivněprávní řešení vybraných otázek vztahujících se k disciplinární odpovědnosti osob ve služebním poměru.

Př́spěvek má v podstatě dvě roviny, přičemž v rámci první z nich jsou, s ohledem na limity jeho rozsahu, nastíněny základní aspekty (či vybrané otázky) pojetí disciplinární odpovědnosti státních zaměstnanců, př́slušníků bezpečnostních sborů a vojáků z povolání. V rovině druhé je pak na podkladu tohoto nástinu proveden pokus o nalezení možností harmonizace jednotlivých pojetí pozitivněprávní úpravy disciplinární odpovědnosti osob ve služebním poměru. Výsledkem tohoto pokusu je několik obecně načrtnutých návrhů na provedení legislativních změn, jimiž by eventuálně mohl být v různém rozsahu upraven text tři výše uvedených zákonů, a které mohou posloužit coby podnět k odborné diskusi. Př́spěvek tedy neprrináší finální řešení, spíše upozorňuje na konkrétní (dlužno dodat, že všechna teoreticky myslitelná) místa pozitivněprávní úpravy, jejichž současná podoba stojí za zvážení.

129 Byt’ byla výše konstatována teoretická jednotnost disciplinární odpovědnosti bez ohledu na toto dělení, neznamená to, že s sebou faktické odlišnosti neprrinášejí rozdíly v pozitivněprávní úpravě. 